\title{
THALLUS AND PHLEGON: SOLAR ECLIPSE IN JERUSALEM c. 33 CE?
}

\author{
N P L Allen (North-West University)
}

\begin{abstract}
The current investigation explores whether Thallus and Phlegon can continue to have relevance to the current historical Jesus debate. To assist in this process, apart from pertinent input from a range of contemporary scholars, the often quoted reference to an assumed solar eclipse that occurred at the time of Jesus of Nazareth's crucifixion is critically examined in the light of current astronomical knowledge. The findings reveal the more likely historical context that is often overlooked by many scholars. As a result, only one conclusion is possible, namely any account of a total solar eclipse at any time during any activity in or around Jerusalem between $23 \mathrm{CE}$ and $43 \mathrm{CE}$ would have to be entirely and undeniably fictitious. In addition, even if one is naïve enough to countenance supposedly historical references to either Thallus or Phlegon, they tell the historian nothing that can authenticate either the life or ministry of Jesus of Nazareth.
\end{abstract}

Keywords: Crucifixion; Eusebius Pamphili; Thallus; George Syncellus; Jesus of Nazareth; Josephus Flavius; Origen Adamantius; Phlegon of Tralles; Sextus Iulius Africanus; solar eclipse; Theophilus of Antioch.

\section{Introduction}

Two ancient authors who are regularly cited by scholars who would claim valid extra-biblical references to Jesus of Nazareth include Thallus ${ }^{1}$ and Phlegon. ${ }^{2}$ This paper sets out to determine whether either of these two cited authorities can continue to have relevance to the current historical Jesus debate. To assist in this process (apart from pertinent input from current scholars), the often quoted reference to a supposed solar eclipse that occurred at the time of Jesus of Nazareth's crucifixion is critically examined in the light of current astronomical knowledge. ${ }^{3}$

Thallus (fl. 112 - 109 BCE?).

Phlegon of Tralles ( $2^{\text {nd }}$ century CE).

Research stems from Allen 2015.

Akroterion 63 (2018) 73-93 


\section{Thallus}

What is of importance to this paper, concerns George Syncellus ${ }^{4}$, the well-known ninth-century CE Byzantine chronicler and ecclesiastic, who composed a chronicle of world history, ${ }^{5}$ in which he quoted directly from a number of earlier chroniclers. Here, Syncellus refers to Julius Africanus ${ }^{6}$ reference to both Thallus ${ }^{7}$ and Phlegon in the context of Jesus' passion and resurrection as described in Ev. Marc. 15.33:

At the sixth hour darkness came over the whole land until the ninth hour.

In this context, Syncellus ${ }^{8}$ states the following:

A most terrible darkness fell over all the world, the rocks were torn apart by an earthquake, and many places both in Judaea and the rest of the world were thrown down. In the third book of his Histories, Thallos dismisses this darkness as a solar eclipse. In my opinion, this is nonsense.

For the Hebrews celebrate the Passover on Luna 14, and what happened to the Saviour occurred one day before the Passover. But an eclipse of the sun takes place when the moon passes under the sun. The only time when this can happen is in the interval between the first day of the new moon and the last day of the old moon, when they are in conjunction. How then could one believe an eclipse took place when the moon was almost in opposition to the sun? So be it. Let what had happened beguile the masses, and let this wonderful sign to the world be considered a solar eclipse through an optical (illusion). Phlegon records that during the reign of Tiberius Caesar there was a complete solar eclipse at full moon from the sixth to the ninth hour; it is clear that this is the one. But what have eclipses to do with an earthquake, rocks breaking apart, resurrection of the dead, and a universal disturbance of this nature? [My emphasis NPLA].

In point of fact, great doubt exists as regards the time in which Thallus lived. ${ }^{9}$ Certainly, it is quite possible that a number of individuals by this name might have

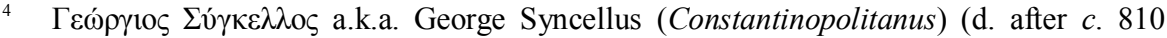
$\mathrm{CE})$.

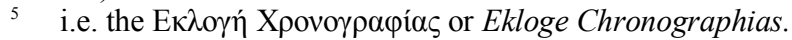

6 Sextus Iulius Africanus a.k.a. Africanus (c. 160 - c. 240 CE).

7 Also referred to as Thallos in some sources.

8 English translation according to Adler \& Tuffin 2002.

Online available: http://www.tertullian.org/rpearse/syncellus/\#E1 [25 June 2014].

9 Carrier already gives a highly detailed account concerning the unreliability of employing Thallus as a valid historical source. $C f$. Carrier 1999. Online available:

http://infidels.org/library/modern/richard_carrier/thallus.html. [13 May 2014]. 
existed and accordingly it is not always clear which one is being specifically mentioned. In addition, the claimed references to the one who is supposed to have had reliable knowledge of Jesus of Nazareth is, more than likely, early Christian invention. Irrespective, purely for the sake of complete accuracy and transparency, the claims that Thallus is a reliable extra-biblical / scriptural authority will be dealt with (albeit) briefly.

\subsection{Arguments in support of authenticity}

Both Bruce ${ }^{10}$ and Miller ${ }^{11}$ date Thallus's work to $52 \mathrm{CE}$. In addition, they both make the claim that this same Thallus produced a chronicle, tracing the history of Greece from the Trojan War up to his own time. Both scholars seem to base their mid-first century CE dating on a misquoted reference to Josephus ${ }^{12}$ (i.e. Antiquities of the Jews 18, 6, 4 / 167). Here, a reference is made to one of Emperor Tiberius' freedmen. Although this freedman's name is not mentioned by Josephus, these two scholars assume that he was called 'Thallus'. Regardless, Miller (1969) goes somewhat further than Bruce, when he, inter alia, tries to back up his early date for Thallus with two references to Africanus. Africanus is quoted by Eusebius ${ }^{13}(P E$, [Praeparatio evangelica], X,10/4) ${ }^{14}$ as follows:

After the seventy years of the Captivity Cyrus became king of Persia, in the year in which the fifty-fifth Olympic festival was held, as one may learn from the Bibliotheca of Diodorus, and the histories of Thallus and Castor, also from Polybius and Phlegon, and from others too who were careful about Olympiads: for the time agreed in all of them.

Later, in the same chapter (i.e. $P E, \mathrm{X}, 10 / 8)^{15}$ Africanus is quoted as follows:

For both the historians of Athens, Hellanicus and Philochorus who wrote The Attic Histories, and the writers on Syrian history, Castor and Thallus, and the writer on universal history, Diodorus the author of the Bibliotheca, and Alexander Polyhistor, and some of our own historians recorded these events more accurately even than all the Attic writers.

\footnotetext{
10 Bruce 1959.

11 Miller 1996. Online available: http://christianthinktank.com/jrthal.html. [6 June 2014].

12 Josephus Flavius $(37-c .100 \mathrm{CE})$.

13 Eusebius Pamphili (260/265 - 339/340 CE).

14 English translation according to Gifford 1903. In Tertullian.org. Online available: http://www.tertullian.org/fathers/eusebius_pe_10_book10.htm [11 August 2014].

15 Ibid.
} 
In this latter regard, Miller $^{16}$ believes that Thallus must have been active a generation before Julius Africanus. Furthermore, merely because Africanus quotes him, Miller is happy to believe that Thallus must have been an important historian of a very high calibre.

Craig, goes somewhat further and sees Thallus as an important witness of a solar eclipse at the time of Jesus of Nazareth's crucifixion event:

The dating of his work is uncertain, but most scholars date Thallus' History to the mid-first century, that is, sometime around $50 \mathrm{CE}$, just 20 years after Jesus' crucifixion in 30 CE. By contrast most scholars date Mark's Gospel to around 66-70 CE. If this right, then either Thallus provides independent, extra-biblical attestation of the darkness at noon, thereby increasing the probability of its historicity, or else Thallus is responding to the passion story which was being told by Christians at his time, thereby attesting to the earliness of that tradition. In either case, Thallus is doubtless reacting to a Christian interpretation of the event, since he is trying to provide an alternative explanation of the event. One could argue that, given his familiarity with Near Eastern affairs, Thallus would have just denied that the event occurred had he no knowledge of its happening. He thereby confirms the historicity of the darkness at noon. ${ }^{17}$

Thus Craig ${ }^{18}$ admits that Thallus's dates are ambiguous yet seems quite content to accept a majority consensus view as regards the date of Syncellus' third-hand, paraphrased utterance. He also, favours an early date for Mark's gospel. Habermas also goes to great lengths to demonstrate that this jaded reference (and others) somehow proves that by 'the middle of the first century' the crucifixion of Jesus was well established in the Mediterranean region. ${ }^{19}$

\subsection{Arguments against authenticity}

According to Carrier ${ }^{20}$ Thallus is first recorded by Theophilus of Antioch in c. 180 CE. In addition, George Syncellus ${ }^{21}$ (previously mentioned) quotes directly from a number of earlier chroniclers, one of whom (as has already been discussed)

16 Miller 1996. Online available: http://christianthinktank.com/jrthal.html. [6 June 2014].

17 Craig 2014. Online available: http://www.reasonablefaith.org/thallus-on-the-darknessat-noon [26 June 2014].

18 Ibid.

19 Habermas 1996:223.

20 Carrier 1999. Online available: http://infidels.org/library/modern/richard_carrier/thallus.html. [13 May 2014].

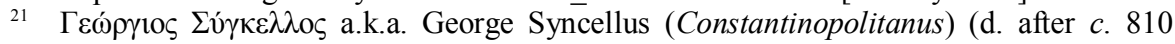
$\mathrm{CE}$ ). 
was none other than Africanus (c. $160-$ c. $240 \mathrm{CE}$ ). It is also well known, that Africanus had a strong influence on Eusebius. ${ }^{22}$

If one is generous and blindly accepts this ambiguous reference to something that an individual called 'Thallus' might have written at an earlier date (i.e. sometime prior to the third century $\mathrm{CE}$ ), we still have the problem that Africanus correctly finds fault in Thallus' reasoning when he naively allows for an antithetical situation wherein a Full Moon and solar eclipse are simultaneously visible. Carrier expertly sums up most of his concerns when he states:

Such a story has obvious mythic overtones and can easily be doubted. That a solar eclipse should mark the death of a king was common lore among Greeks and other Mediterranean peoples (Herodotus 7.37, Plutarch Pelopidas 31.3 and Aemilius Paulus 17.7-11, Dio Cassius 55.29.3, John Lydus De Ostentis 70.a), and that such events corresponded with earthquakes was also a scientific superstition (Aristotle Meteorology 367.b.2, Pliny Natural History 2.195, Virgil Georgics 2.47.478-80). It was also typical to assimilate eclipses to major historic events, even when they did not originally correspond, or to invent eclipses for this purpose (Préaux claims to have counted 200 examples in extant literature; Boeuffle and Newton have also remarked on this tendency). The gospel stories also make a solar eclipse impossible: the crucifixion passover happened during a full moon, and the darkness supposedly lasted three hours (indeed, Julius Africanus claimed it covered the whole world). Such an impossible event would not fail to be recorded in the works of Seneca, Pliny, Josephus or other historians, yet it is not mentioned anywhere else outside of Christian rhetoric, so we can probably dismiss the idea of this being a real event. ${ }^{23}$

Apart from the fact that we have no way of confirming Thallus' writings as bona fide eyewitness reports, and given the far-fetched nature of his accounts, only someone who gullibly believed in the occurrence of both unnecessary as well as unnatural geological and cosmic events could claim this as being an extra-biblical / scriptural reference to Jesus of Nazareth.

Carrier $^{24}$ also confirms that historians do not know when Thallus wrote. Scholars who claim that this occurred in c. $52 \mathrm{CE}$ are basing their findings solely on a conjectural emendation of a corrupted text. It should be emphasised that the

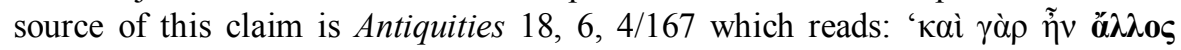

22 Cf. Carrier 2012b:185-191.

23 Carrier 1999. Online available:

http://infidels.org/library/modern/richard_carrier/thallus.html. [13 May 2014].

${ }^{24}$ Carrier 2012a:188. 


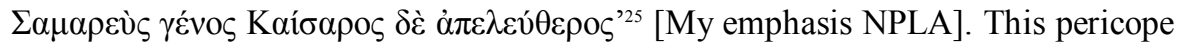
is seemingly translated by Whiston as 'Now there was one Thallus, a freed-man of Caesar'. ${ }^{26}$ This is extraordinary, because no mention is made of a Thallos in the Greek text, yet the most common English translations repeatedly yield this enigmatic name. The reason, it transpires, is due to a deliberate alteration made by Hudson $^{27}$ in his posthumous translation of 1720 (Oxford University publication in two volumes), wherein he felt that the term $\alpha \lambda \lambda \circ \varsigma$ made no sense and based purely on a personal speculation changed it to $\Theta \alpha \lambda \lambda$ ó $^{28}{ }^{28}$ On this issue, Carrier $^{29}$ explains:

The addition of the letter theta $(\mathrm{TH})$ was conjectured by a scholar named Hudson in 1720, on the argument that ALLOS didn't make sense, and that Thallus was the attested name of an imperial freedman of Tiberius in inscriptions: in his own words, 'I put "Thallos" in place of "allos" by conjecture, as he is attested to have been among the freedmen of Tiberius, going by the inscriptions of Gruter' (p. 810, translated from Hudson's Latin).

Carrier $^{30}$ also draws our attention to an Armenian translation of Eusebius' Pantodape historia a.k.a. the Chronicle, in which Eusebius says he employed three volumes from Thallus covering the period from the sack of Troy (c.1200 BCE) to the $167^{\text {th }}$ Olympiad (i.e. c. 109 BCE). Carrier confirms that, if authentic, this would mean that Thallus wrote about events ending in $c$. $109 \mathrm{BCE}$ and accordingly far too early to coincide with a mid-first century $\mathrm{CE}$ event.

Lee $^{31}$ reminds his reader that due to damage in the Syncellus manuscript, Thallus's true name is not known. He also correctly states that 'third-hand hearsay is not compelling proof of a worldwide darkness that everyone should have noticed'. ${ }^{32}$

25 Greek according to William Whiston's translation 1895. Perseus Digital Library, http:// www.perseus.tufts.edu/hopper/text?doc=Perseus\%3Atext\%3A1999.01.0146\%3Abook\% 3D18\%3Awhiston\%20chapter\%3D6\%3Awhiston\%20section\%3D4 [3 ${ }^{\text {rd }}$ July 2016].

26 Ibid.

27 I.e. the English classical scholar: John Hudson (1662-1719).

28 Carrier 1999. Online available: http://infidels.org/library/modern/richard_carrier/thallus.html. [13 May 2014].

29 Carrier 1999. Online available: http://infidels.org/library/modern/richard_carrier/thallus.html. [13 May 2014].

30 Carrier 2012a:188.

31 Lee 2014. Online available: http://www.patheos.com/blogs/daylightatheism/essays/choking-on-the-camel-part2/\#lucian [10 July 2014].

32 Ibid. 
Lowder states: 'Since we don't possess any extant copies of the Thallus material, there is simply no way to know if Thallus was a witness to Jesus. Likewise, we don't know what Thallus' sources were'. ${ }^{33}$ Wells would likely support both Lee and Lowder's arguments. In a rebuttal aimed at Bruce, ${ }^{34}$ he quips: 'To use him [Thallus] as evidence that a Christian Passion narrative existed as early as 52 CE is fantastic ${ }^{35}$ [My insertion NPLA].

\section{Phlegon}

Hansen, ${ }^{36}$ confirms that Phlegon of Tralles is perhaps best known for having written the Olympiads presumably sometime in the early second century CE. Regardless, this work is now only partially preserved via the writings of, inter alia, Origen $^{37}$ and Eusebius. In this context, Origen makes a reference to Phlegon in his Cels. (Contra Celsus), 2, 14, ${ }^{38}$ where he is quoted as follows:

Now Phlegon, in the thirteenth or fourteenth book, I think, of his Chronicles, not only ascribed to Jesus a knowledge of future events (although falling into confusion about some things which refer to Peter, as if they referred to Jesus), but also testified that the result corresponded to His predictions. So that he also, by these very admissions regarding foreknowledge, as if against his will, expressed his opinion that the doctrines taught by the fathers of our system were not devoid of divine power.

Origen makes another reference to Phlegon in his Cels. 2, 33 and 59:

And with regard to the eclipse in the time of Tiberius Cæsar, in whose reign Jesus appears to have been crucified, and the great earthquakes which then took place, Phlegon too, I think, has written in the thirteenth or fourteenth book of his Chronicles ... He [Celsus] imagines also that both the earthquake and the darkness were an invention; but regarding these, we have in the preceding pages, made our defence, according to our ability, adducing the testimony of Phlegon, who relates that these events took place at the time when our Saviour suffered. [My insertion NPLA].

33 Lowder 2000. Online available:

http://www.infidels.org/library/modern/jeff_lowder/jury/chap5.html [1 Sept. 2014].

34 Frederick Fyvie Bruce.

35 Wells 1988:18.

36 Hansen 1996:xvi; 215.

37 Origen Adamantius (184-253 CE).

38 English translation according to The works of Origen (s.a.). Online available: http://www.john-uebersax.com/plato/origen2.htm [1 June 2014]. 
Jerome wrote in his Chronicle: $202^{\text {nd }}$ Olympiad: 18 and 19:39

Phlegon, who is an excellent calculator of Olympiads, also writes about these things, writing thus in his thirteenth book: In the fourth year, however, of Olympiad 202, an eclipse of the sun happened, greater and more excellent than any that had happened before it; at the sixth hour, day turned into dark night, so that the stars were seen in the sky, and an earthquake in Bithynia toppled many buildings of the city of Nicaea. These things [are according to] the aforementioned man.

In addition, as has already been ascertained (ut supra) we also have Syncellus' reference to Africanus' reference to both Thallus and Phlegon where we are told, in the context of the passion and resurrection of the Christ, that 'Phlegon records that during the reign of Tiberius Caesar there was a complete solar eclipse at full moon from the sixth to the ninth hour ....' ${ }^{40}$

\subsection{Arguments in support of authenticity}

According to Habermas, ${ }^{41}$ Phlegon was a secular historian who was born $c .80 \mathrm{CE}$ and who lived during the second century CE. In additon, McDowell ${ }^{42}$ takes it for granted that Phlegon is a reliable source for the historicity of Jesus.

\subsection{Arguments against authenticity}

Carrier ${ }^{43}$ supports the assertion that Phlegon could only have written in the decade c. 140-149 CE and is already well known for relating fanciful stories. In this connection he concludes that it would not be out of the ordinary for Phlegon to borrow such a tale from Christian literature. In addition Carrier ${ }^{44}$ refers to the well-known classical scholar, Routh ${ }^{45}$ who questions why Africanus, having just criticised Thallus, goes on to view Phlegon in a more positive light. This is peculiar, given that both authors stated the self-same concept. Routh also noticed grammatical evidence that would seem to indicate interpolation of the Phlegon

39 English translation based on the online edition at Tertullian Project. Online available: http://www.tertullian.org/fathers/jerome_chronicle_03_part2.htm [13 May 2014].

40 English translation according to Adler \& Tuffin $19 \overline{8} 4$.

Online available: http://www.tertullian.org/rpearse/syncellus/\#E1 [25 June 2014].

41 Habermas 1996:217.

42 McDowell 1979:84.

43 Carrier 1999. Online available:

http://infidels.org/library/modern/richard_carrier/thallus.html. [13 May 2014].

44 Ibid.

45 I.e. Martin Joseph Routh (1755-1854). Cf. Routh 1846. 
reference in Africanus' text. The upshot of this is that the testimonial to Phlegon appears to be both grammatically and logically out of place.

Wells $^{46}$ feels that Phlegon was merely reporting on an eclipse that most likely occurred on 24 November $29 \mathrm{CE}$ and that it was Africanus who linked this astronomical reference to the claimed supernatural events at Christ's passion. Whereas Lee ${ }^{47}$ emphasises that like Thallus, Phlegon's major works, the Chronicles and the Olympiads, have been lost. At best we only have unsubstantiated references made by early Christian apologists like Origen, Eusebius and Iulius Africanus. Here again the latter writer is himself referenced by a ninth century apologist (i.e. George Syncellus). Furthermore, Lee ${ }^{48}$ reminds his reader that Phlegon lived at least a century after the events he claims personally to have witnessed (i.e. as cited by later writers).

\section{4. $\quad$ Solar eclipses visible in Jerusalem (c. 23-43 CE)}

One quick and efficient way to ascertain Thallus' and Phlegon's continued usefulness as supposed extra-biblical references is to compare the outcomes of the critique undertaken of the classical literature with the findings of modern science. In this way, we can further critically evaluate Thallus' and Phlegon's claim that Jesus of Nazareth was crucified during a notable solar eclipse. Here, we must allow for a modicum of hyperbole in the ancient texts. However we will obviously exclude ridiculous claims that the darkness was a supernatural event visible around the entire globe. Moreover, if these ancient sources are to be trusted in any way, then there must have been some appropriate astronomical or natural event. This occurrence must also have been genuinely witnessed by a number of individuals (i.e. a multiplicity of reliable substantiated sources). We have to assume that the claimed eclipse (a la Eusebius, Africanus, Thallus and Phlegon etc.) was visible in Jerusalem within a few years of the hypothetical date of the crucifixion of Jesus of Nazareth (i.e. c. $33 \mathrm{CE}$ ). Finally, if it can be demonstrated that no eclipse occurred at the time of the purported crucifixion even $t^{49}$ it both proves the worthlessness of employing Thallus and Phlegon as reliable sources as well as illustrating that the solar eclipse/darkness is a at best some rhetorical device.

46 Wells 1988:4.

47 Lee 2014. Online available:

http://www.patheos.com/blogs/daylightatheism/essays/choking-on-the-camel-part2/\#lucian [10 July 2014].

48 Ibid.

49 This includes any time reasonably close to the claimed event. In an attempt to be totally fair, the author has considered astronomical data up to a century beyond the conventional range of assumed crucifixion dates. 
The information supplied below is not meant to be the last word on eclipses but merely serves to show the more likely historical context that is often overlooked by many scholars. Further, we must assume that this purely natural and astronomical event was a total eclipse of the Sun by the Moon and not merely some partial or annular eclipse. Indeed, if we allow for annular eclipses, due to the distance of the Moon from the Earth, the lunar diameter appears smaller from Earth, and accordingly the Sun is not totally occluded. In short, ideally speaking, we need a period of measurable / noticeable time when there was a complete masking of the Sun and the sky went totally dark, preferably on or around noon.

As should be well known and as is confirmed by both Syncellus and $\mathrm{NASA}^{50}$ an eclipse of the Sun can only occur during a New Moon. This is as a result of the Sun and the Moon being in almost perfect conjunction as seen from earth. This alignment of the three astronomical bodies is referred to by astronomers as syzygy.

According to mathematical calculations undertaken by NASA ${ }^{51}$ and based on a 5000 -year period of solar eclipses, there are a minimum of two (i.e. $72.5 \%$ of the time) and a maximum of five (i.e. $0.5 \%$ of the time) solar eclipses in any one calendar year. In the first century $\mathrm{CE}$ of the 248 solar eclipses that occurred, only 58 (i.e. $23.7 \%$ ) were total eclipses. Of the 248 eclipses, only a small portion (2.6\%) were central and non-central ${ }^{52}$ (one limit) events whereas $97.3 \%$ were central (twolimit) events.

Therefore, as the eclipse is synonymous with the Moon's shadow (umbra) as it traces a line across the earth's surface, it is totally impossible for a total eclipse over the entire planet let alone three solid hours in one geographical location. Certainly, an occasion for total darkness of the sky is extremely rare for even a small percentage of the earth's surface. When it does occur, although the entire process may last up to two hours as viewed from one location, the longest period possible for a total event (i.e. complete darkness) is some 7.4 minutes. More normally this event lasts anywhere from between two to five minutes.

The NASA table (Table 1) details the shortest and longest solar eclipses of the first century CE. This encompasses all types of solar eclipses, regardless of whether they were total, partial, annular or hybrid:

50 Cf. NASA Eclipse Website. Online available:

http://eclipse.gsfc.nasa.gov/SEcat5/SE0001-0100.html [17 July 2014].

51 Cf. NASA Eclipse Website. Online available: http://eclipse.gsfc.nasa.gov/SEcat5/SE0001-0100.html [17 July 2014].

52 According to NASA, a central solar eclipse occurs when the central axis of the Moon's shadow strikes the Earth's surface. A partial or penumbral eclipse occurs when the axis of the Moon's shadow misses the Earth. $C f$. NASA Eclipse Website. Online available: http://eclipse.gsfc.nasa.gov/SEcatmax/SE4001-5000MaxH.html [17 July 2014]. 


\begin{tabular}{|c|c|c|c|}
\hline Extrema Type & Year & Date & Duration \\
\hline $\begin{array}{l}\text { Longest Annular Solar } \\
\text { Eclipse }\end{array}$ & 96 & 04 November & $11 \mathrm{~m} 18 \mathrm{~s}$ \\
\hline $\begin{array}{l}\text { Shortest Annular Solar } \\
\text { Eclipse }\end{array}$ & 40 & 24 October & $00 \mathrm{m08s}$ \\
\hline $\begin{array}{l}\text { Longest Total Solar } \\
\text { Eclipse }\end{array}$ & 96 & 10 May & $06 \mathrm{~m} 47 \mathrm{~s}$ \\
\hline $\begin{array}{l}\text { Shortest Total Solar } \\
\text { Eclipse }\end{array}$ & 31 & 03 November & $01 \mathrm{~m} 04 \mathrm{~s}$ \\
\hline $\begin{array}{l}\text { Longest Hybrid Solar } \\
\text { Eclipse }\end{array}$ & 41 & 19 April & $01 \mathrm{~m} 24 \mathrm{~s}$ \\
\hline $\begin{array}{l}\text { Shortest Hybrid Solar } \\
\text { Eclipse }\end{array}$ & 86 & 31 May & $00 \mathrm{m08s}$ \\
\hline $\begin{array}{l}\text { Largest Partial Solar } \\
\text { Eclipse }\end{array}$ & 68 & 19 May & - \\
\hline $\begin{array}{l}\text { Smallest Partial Solar } \\
\text { Eclipse }\end{array}$ & 94 & 01 July & - \\
\hline
\end{tabular}

\section{Table 1}

Extreme durations and magnitudes of solar eclipses in the first century $C E$ (Based on a table from NASA Eclipse Website (2014) ${ }^{53}$

According to the NASA data found in Table 1, the nearest solar eclipse (albeit the shortest total eclipse of the first century $\mathrm{CE}$ ) to have occurred relative to $c .33 \mathrm{CE}$ was a total solar eclipse in $31 \mathrm{CE}$ that lasted all of 1 minute and 4 seconds. Below is a NASA reconstruction (Fig. 1) of that event which clearly shows that this event did not occur anywhere near Jerusalem.

$53 \quad C f$. NASA Eclipse Website. Online available:

http://eclipse.gsfc.nasa.gov/SEcat5/SE0001-0100.html [17 July 2014]. 


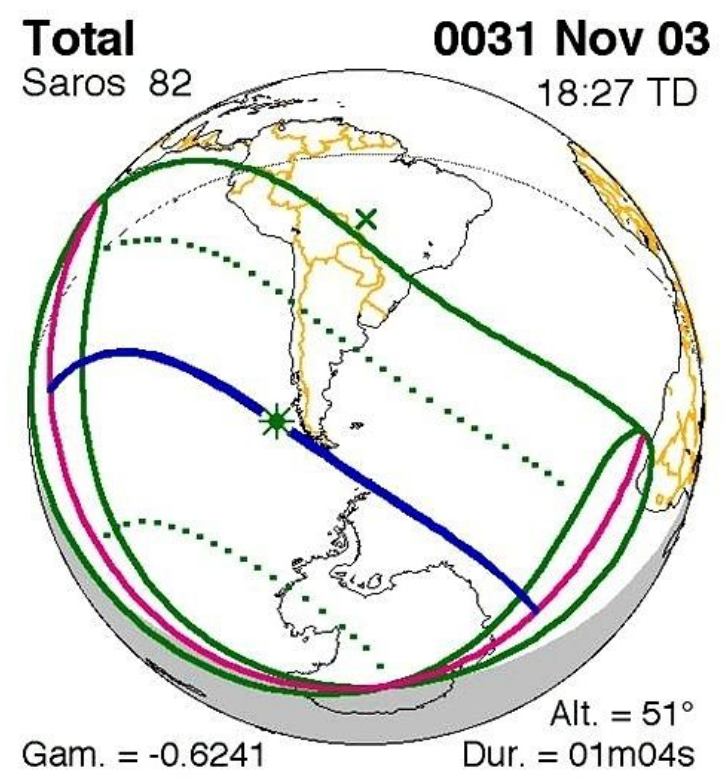

Five Millennium Canon of Solar Eclipses (Espenak \& Meөus)

Fig. 1: Diagram showing path of Moon's central axis shadow on $3^{\text {rd }}$ November 31 CE (Diagram taken from NASA Eclipse Website [2014]) ${ }^{54}$

Based on the NASA data it is also possible to surmise that the longest time any total solar eclipse lasted in the first century CE was 6 minutes and 47 seconds. Fig. 2 shows the path of the Moon's central axis shadow for that event on $10^{\text {th }}$ May $96 \mathrm{CE}$ :

${ }^{54} C f$. NASA Eclipse Website. Online available:

http://eclipse.gsfc.nasa.gov/5MCSEmap/0001-0100/31-11-03.gif [17 July 2014]. 


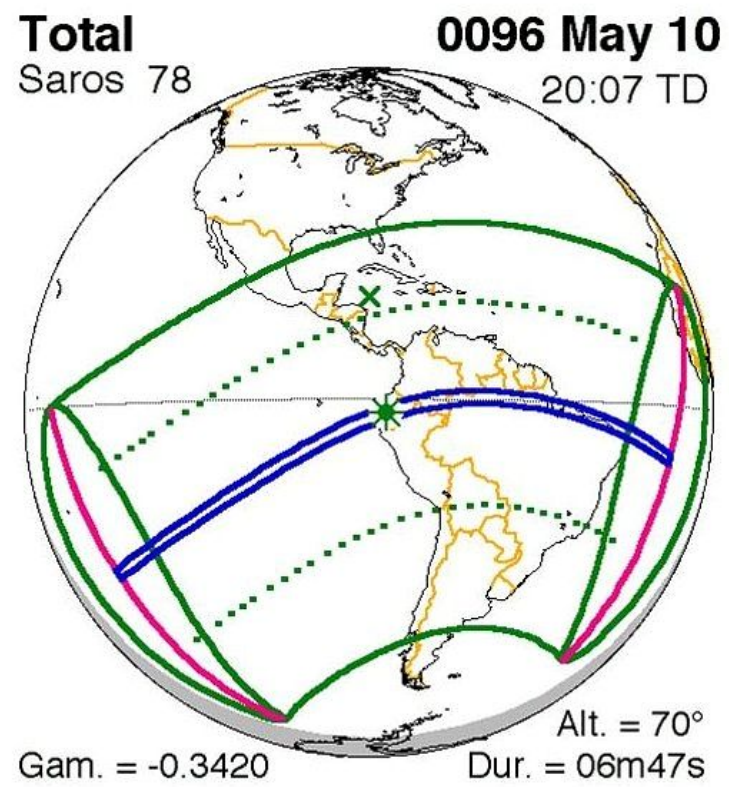

Five Millennium Canon of Solar Eclipses (Espenak \& Meөus)

Fig. 2: Diagram showing path of Moon's central axis shadow on $10^{\text {th }}$ May 96 CE (Diagram taken from NASA Eclipse Website [2014]) ${ }^{55}$

Again, this eclipse occurred nowhere near the Middle East. Other eclipses (i.e. both annular and total) which at a stretch of the imagination scholars might want to be considered as candidates for Thallus and Phlegon's total darkness at noon and which occurred between 23 and $43 \mathrm{CE}^{56}$ as calculated by NASA (2014) are presented below ( $c f$. Table 2):

$55 C f$. NASA Eclipse Website. Online available:

http://eclipse.gsfc.nasa.gov/5MCSEmap/0001-0100/96-05-10.gif [17 July 2014].

56 Although it is seen that no solar eclipses from the first century CE meet the sought after requirements, special attention is given to those astronomical events that occurred a decade either side of the more commonly accepted crucifixion date (i.e. $33 \mathrm{CE}$ ). 


\begin{tabular}{|c|c|c|c|c|c|}
\hline $\begin{array}{l}\text { Year } \\
\text { CE }\end{array}$ & Date & $\begin{array}{l}\text { Time of } \\
\text { Greatest } \\
\text { Eclipse }\end{array}$ & $\begin{array}{l}\text { Type of } \\
\text { Eclipse }\end{array}$ & $\begin{array}{l}\text { Central } \\
\text { Duration }\end{array}$ & $\begin{array}{c}\text { Closest Location of } \\
\text { Greatest Eclipse to } \\
\text { Jerusalem }\end{array}$ \\
\hline 23 & 03 October & $16: 31$ & Annular & $05 \mathrm{~m} \mathrm{07s}$ & Zimbabwe \\
\hline 24 & 28 March & $13: 52$ & Total & $04 \mathrm{~m} 24 \mathrm{~s}$ & Madagascar \\
\hline 24 & 21 September & $17: 57$ & Annular & $08 \mathrm{m05s}$ & Libya \\
\hline 26 & 06 February & $10: 26$ & Annular & $01 \mathrm{~m} 12 \mathrm{~s}$ & Border of Egypt \& Sudan \\
\hline 26 & 01 August & $12: 55$ & Total & $02 \mathrm{~m} 53 \mathrm{~s}$ & Botswana \\
\hline 27 & 26 January & $16: 02$ & Annular & $07 \mathrm{~m} 34 \mathrm{~s}$ & Somalia \\
\hline 27 & 22 July & $04: 29$ & Total & $06 \mathrm{~m} 31 \mathrm{~s}$ & Bay of Bengal \\
\hline 28 & 15 January & $15: 44$ & Annular & $07 \mathrm{m01s}$ & Southern Indian Ocean \\
\hline 28 & 10 July & $21: 28$ & Total & $03 m 30 s$ & France \\
\hline 29 & 24 November & $12: 15$ & Total & $01 \mathrm{~m} 59 \mathrm{~s}$ & Qatar \\
\hline 30 & 21 May & 04:10 & Annular & $06 \mathrm{m09s}$ & Australia \\
\hline 30 & 14 November & 03:37 & Total & $04 \mathrm{m08s}$ & Southern China \\
\hline 31 & 10 May & $04: 46$ & Annular & $04 m 26 s$ & East of Sri Lanka \\
\hline 31 & 03 November & $18: 26$ & Total & $01 \mathrm{m04s}$ & Tierra del Fuego \\
\hline 33 & 19 March & $13: 40$ & Total & $04 \mathrm{m06s}$ & Indian Ocean \\
\hline 33 & 12 September & $12: 47$ & Annular & $06 \mathrm{m09s}$ & Northern Kazakhistan \\
\hline 34 & 09 March & $06: 20$ & Total & $04 m 56 s$ & Indian Ocean \\
\hline 34 & 01 September & $13: 52$ & Annular & $04 \mathrm{~m} 20 \mathrm{~s}$ & Chad \\
\hline 35 & 26 February & $20: 29$ & Hybrid & $00 \mathrm{~m} 31 \mathrm{~s}$ & New Mexico, USA \\
\hline 35 & 21 August & $21: 43$ & Hybrid & $01 \mathrm{~m} 13 \mathrm{~s}$ & South Pacific Ocean \\
\hline 37 & 05 January & $10: 17$ & Annular & $06 \mathrm{~m} 40 \mathrm{~s}$ & Antarctica \\
\hline 37 & 01 July & $21: 23$ & Total & $03 \mathrm{~m} 54 \mathrm{~s}$ & Ontario, Canada \\
\hline 37 & 25 December & $12: 47$ & Annular & $04 \mathrm{~m} 15 \mathrm{~s}$ & South Africa \\
\hline 38 & 21 June & 09:34 & Hybrid & $03 \mathrm{~m} 54 \mathrm{~s}$ & India \\
\hline 38 & 14 December & $22: 33$ & Hybrid & $01 \mathrm{~m} 19 \mathrm{~s}$ & West of Mexico \\
\hline 40 & 24 October & $16: 37$ & Annular & $00 \mathrm{m08s}$ & East of Tierra del Fuego \\
\hline 41 & 19 April & $07: 54$ & Hybrid & $01 \mathrm{~m} 24 \mathrm{~s}$ & Thailand \\
\hline 41 & 14 October & $00: 26$ & Annular & $05 \mathrm{~m} 47 \mathrm{~s}$ & South Pacific Ocean \\
\hline 42 & 08 April & $21: 32$ & Total & $05 \mathrm{~m} 05 \mathrm{~s}$ & $\begin{array}{l}\text { South America, centred } \\
\text { west of Peru }\end{array}$ \\
\hline 42 & 03 October & $01: 27$ & Annular & $08 \mathrm{~m} 56 \mathrm{~s}$ & North Pacific Ocean \\
\hline
\end{tabular}

Table 2: Table showing all annular, hybrid and total eclipses that occurred between 25 and 45 CE (Information based on various tables supplied by NASA 2014) ${ }^{57}$

57 Cf. NASA Eclipse Website. Online available:

http://eclipse.gsfc.nasa.gov/SEcat5/SE0001-0100.html [17 July 2014]. 
It is clearly evident that the nearest total eclipse to have occurred in or around Jerusalem in a twenty-year window would have to have been 24 November 29 CE. Here, a total solar eclipse, centred on Qatar for a maximum of 1 minute and 59 seconds was also briefly visible along a line which crossed, inter alia, Romania, Turkey, Syria, Saudi Arabia and India (cf. Fig. 3). This event reached its peak at 12:15 in Qatar.

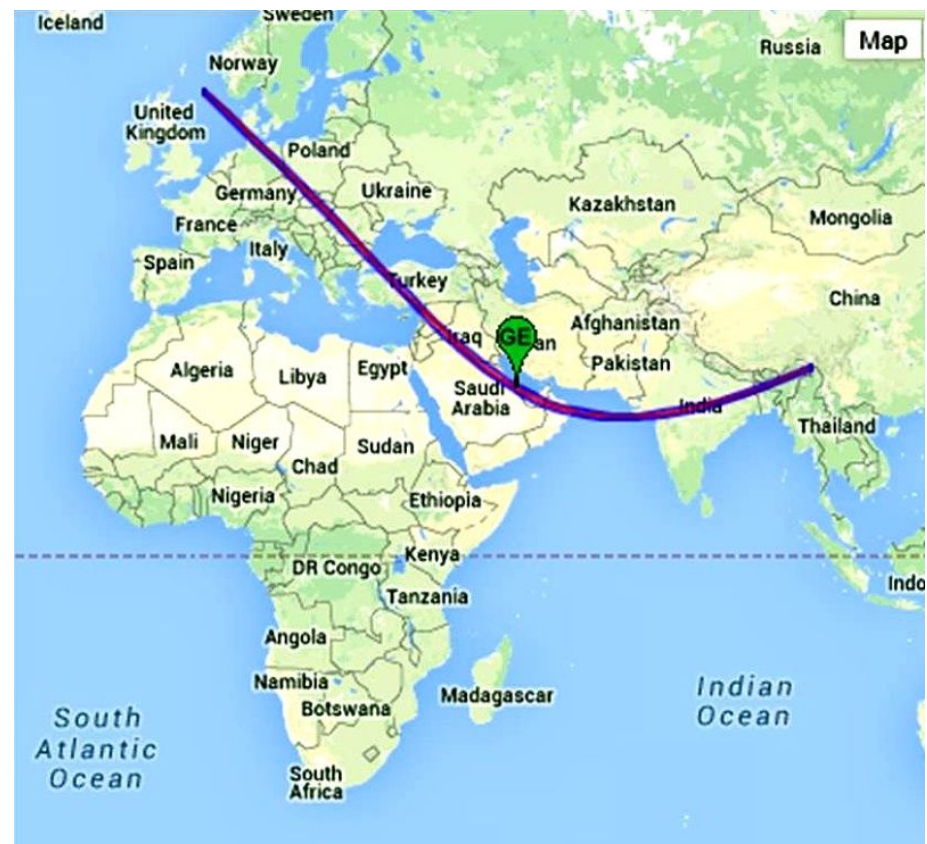

Fig. 3: Path of the Moon's shadow on $24^{\text {th }}$ November 29 CE (General view). (Image taken from NASA Eclipse Website, 2014) ${ }^{58}$

Eclipse map courtesy of Fred Espenak - NASA/Goddard Space Flight Center ${ }^{59}$

$58 \quad C f$. NASA Eclipse Website. Online available:

http://eclipse.gsfc.nasa.gov/SEsearch/SEsearchmap.php?Ecl=00291124 [17 July 2014].

59 For more information on solar and lunar eclipses, see Fred Espenak's Eclipse Web Site.

Online available: http://eclipse.gsfc.nasa.gov/eclipse.html [17 July 2014]. 
The Moon's umbra passed by Jerusalem on $24^{\text {th }}$ November 29 CE. The NASA map (Fig. 4) below shows the path of the solar eclipse as it traversed the surface of the earth. The path of the moon is indicated by a shaded area demarcated by three parallel lines. These in turn represent the northern, central and southern path limits. Here, the central line indicates the only point on the earth's surface where a total eclipse would have been visible.

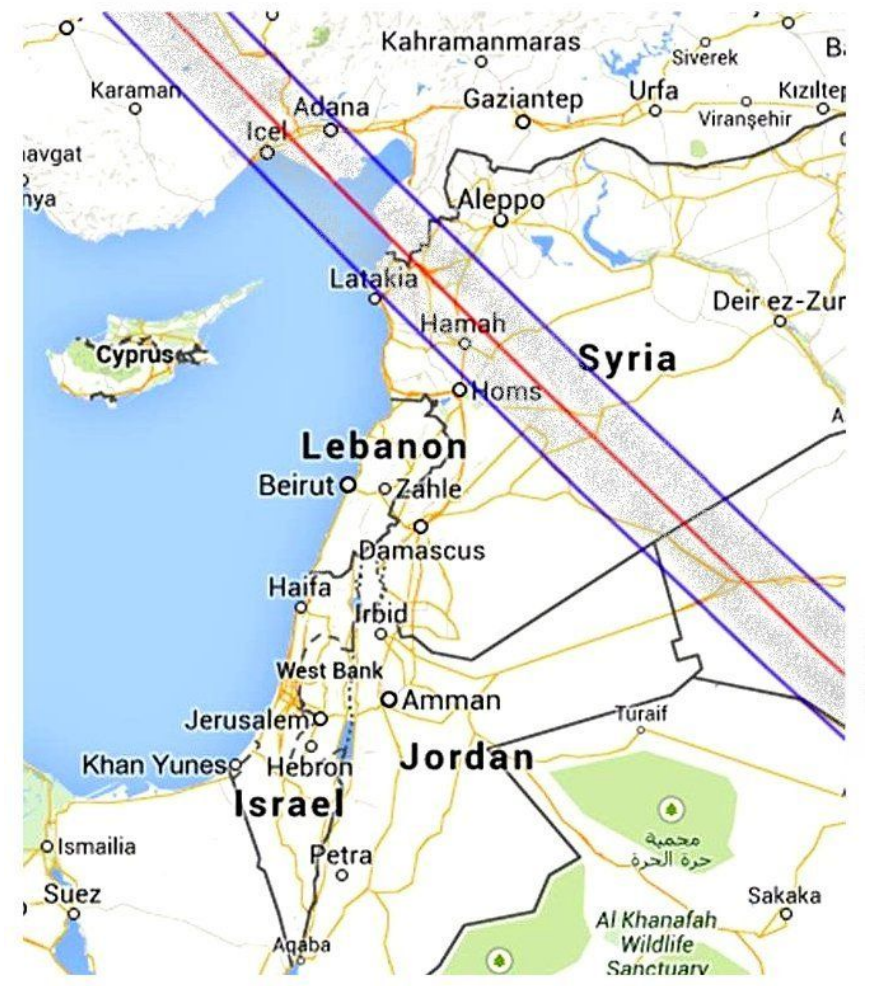

Fig. 4: Path of the Moon's shadow on $24^{\text {th }}$ November 29 CE (Detailed view). (Image taken from NASA Eclipse Website, 2014) ${ }^{60}$

Eclipse map courtesy of Fred Espenak - NASA/Goddard Space Flight Center ${ }^{6 l}$

${ }^{60} C f$. NASA Eclipse Website. Online available:

http://eclipse.gsfc.nasa.gov/SEsearch/SEsearchmap.php?Ecl=00291124 [17 July 2014].

${ }_{61}$ For more information on solar and lunar eclipses, see Fred Espenak's Eclipse Web Site.

Online available: http://eclipse.gsfc.nasa.gov/eclipse.html [17 July 2014]. 
As a result, anyone standing in Jerusalem on that day would have only seen the Moon's penumbra and accordingly, they may have witnessed a partial eclipse, where at its peak (i.e. 08:44) the Sun would have been occluded by $90.55 \%$ for a few seconds. Table 3 (ut infra) gives the exact details of this event based on the NASA calculation:

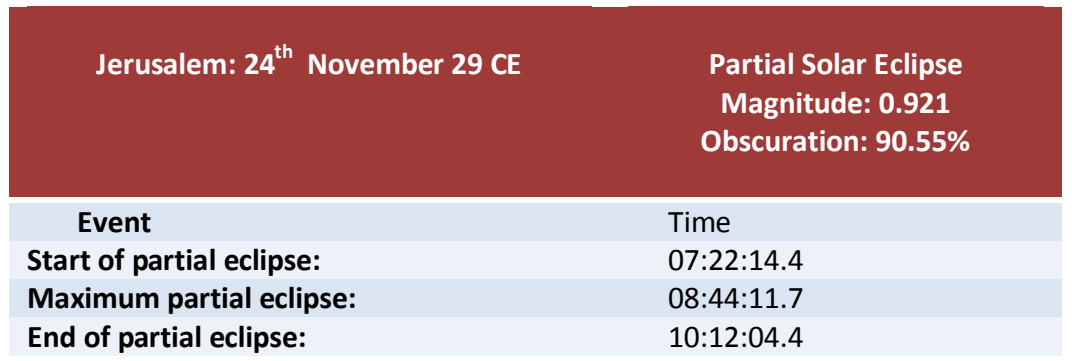

Table 3: Details of a partial solar eclipse observed in Jerusalem on $24^{\text {th }}$ November 29 CE (Table adapted from NASA Eclipse Website, 2014) ${ }^{62}$

\section{Discussion}

Considering that the synodic period of the Moon's orbit (i.e. as viewed from the Earth) is exactly 29.5305882 days, a solar eclipse can only happen some two weeks before or after the beginning of Passover. In addition, Passover always occurs in the spring period in Israel (i.e. April / May). Therefore, if the gospel accounts of an apparent total solar eclipse are accurate, then any crucifixion (including that claimed for Jesus of Nazareth) could not possibly have occurred at Passover. For the sake of argument, one might also want to hypothesise the following, viz:

1. The partial eclipse that occurred on the early morning of 24 November $29 \mathrm{CE}$ (Fig. 4) somehow served as an inspiration for subsequent exaggerated accounts of total darkness for three hours in the afternoon; and

2. There was an actual crucifixion of Jesus of Nazareth that occurred on that day.

$62 C f$. NASA Eclipse Website. Online available:

http://eclipse.gsfc.nasa.gov/SEsearch/SEsearchmap.php?Ecl=00291124 [17 July 2014]. 
However if the above premises are both true then it follows that:

1. If Jesus of Nazareth was crucified at noon and taken down three hours later, no darkness ever occurred during the process.

2. If there was ever a brief darkening of the sky there was neither a crucifixion on a Passover festival nor at noon.

3. If the crucifixion happened at the Passover there was no darkness.

Therefore, if the crucifixion at Passover account in the $N T$ is accurate then no solar eclipse occurred. Finally, if one (purely for the sake of interest) attempts to find an eclipse, as calculated by NASA, which occurred in the months of April or May in the Middle East sometime between 23 and $43 \mathrm{CE}$ we see that the closest possible factual event was an annular eclipse centred near Sri Lanka on 10 May 31 CE. The latter could not possibly have caused a total eclipse in Jerusalem. Neither could the event in $29 \mathrm{CE}$ which occurred some six months after Passover and which could not possibly have caused total darkness for the observers in Jerusalem.

\section{Conclusion}

We are left with the only conclusion possible, namely any account of a total solar eclipse at any time during any activity in or around Jerusalem between 23 and 43 $\mathrm{CE}$ including Roman crucifixions and the like, would have to be entirely and undeniably fictitious.

Taken at face value, it would appear that Phlegon is at best confirming the traditional Christian crucifixion date of $33 \mathrm{CE}$ with a flawed reference to the ancient Olympiad dating system. ${ }^{63}$ In addition, assuming that he was a nonChristian, non-partisan commentator, he either said or is made to say, that he verifies the accuracy of certain unspecified and unrecorded predictions made by Jesus. It is also clear that Origen's primary purpose for employing this reference is to prove that Christianity is based on divine authority, proven by fulfilment of prophecy.

His secondary reason for quoting Phlegon is to confirm that Jesus' death was a major, if not global, event of supernatural proportions. It is less likely that Origen sees this account as important evidence for Jesus' historical existence. Eusebius, on the other hand seems to be more concerned with the latter issue, viz.:

63 Based on the assumption that the first Olympiad dates from 776-772 BCE it follows that the $202^{\text {nd }}$ Olympiad commenced in $32 \mathrm{CE}$ and thus, the fourth year of the $202^{\text {nd }}$ Olympiad was in 35 CE. Strictly speaking Phlegon should have been quoted as stating that the solar eclipse and associated earthquake occurred in the first year of the $202^{\text {nd }}$ Olympiad. 
the need for historical validation for Jesus' existence. It should also be seen as significant that, on two separate occasions, Origen cannot quite remember where he had seen the information that he happily paraphrases for posterity, whereas Eusebius knows exactly where the information resides and quotes Phlegon verbatim.

As with Thallus even if one rashly accepts on pure faith that the reference to Phlegon is accurate, it still tells the historian very little that can authenticate the life and ministry of Jesus of Nazareth.

\section{BIBLIOGRAPHY}

Adler, W \& Tuffin, P (eds.) 2002. The chronography of George Synkellos: A Byzantine chronicle of universal history from the creation. Oxford: Oxford University Press.

Allen, N P L 2015. Clarifying the scope of pre-fifth-century CE Christian interpolation in Josephus' Antiquitates Judaica (c. 94 CE). Unpublished Ph.D. Thesis. Potchefstroom, South Africa: North-West University.

Carrier, R 2012a. Proving history: Bayes' theorem and the quest for the historical Jesus. Amherst, NY: Prometheus Books.

_ 2012b. Thallus and the darkness at Christ's death. Journal of Greco-Roman Christianity and Judaism 8:185-191. Sheffield: Phoenix Press.

Cohen, L \& Manion, L 1994. Research methods in education. $4^{\text {th }}$ ed. London: Routledge.

Creswell, J W 2003. Research design: Qualitative, quantitative and mixed methods approaches. Thousand Oaks: Sage.

Derrida, J 1999. Hospitality, justice and responsibility. In Dooley, M \& Kearney, R (eds.), Questioning ethics: Contemporary debates in philosophy, 65-83. London: Routledge.

Gifford, E H (ed. and trans.) 1903. Eusebii Pamphili: Evangelicae praeparationis, libri XV, tomus III. Londinensis: Oxonii E Typographeo Academico.

Habermas, G R 1996. The historical Jesus: Ancient evidence for the life of Christ. Joplin, MO: College Press Publishing.

Hansen, W (trans.) 1996. Phlegon of Tralles' book of marvels. Exeter: University of Exeter Press.

Jacoby, F (ed. \& trans.) 1923. Die Fragmente der griechischen Historiker, Vols 1-3, Leiden: E J Brill \& Co.

Kukla, A 2000. Social constructivism and the philosophy of science. New York, NY: Routledge.

McDowell, J 1979. Evidence that demands a verdict. Nashville: Thomas Nelson. 
Mertens, D M 2005. Research methods in education and psychology: Integrating diversity with quantitative and qualitative approaches, $2^{\text {nd }}$ ed. Thousand Oaks: Sage.

Mosshammer, A A (ed.) 1984. Georgius Syncellus, Ecloga Chronographica. Leipzig: Tübner.

Pouliot, V 2007. 'Sobjectivism': Toward a constructivist methodology. International Studies Quarterly 51:359-384.

Routh, M J 1846. Reliquiae sacrae: Sive auctorum fere jam perditorum secundi tertiique saeculi post Christum natum quae supersunt. Accedunt synodi, et epistolae canonicae, Nicaeno concilio antiquiores. Ad Codices Mss. recensuit, notisque illustravit. Editio Altera. $2^{\text {nd }}$ ed. vol. 2. Oxford: Oxford University Press.

Wells, G A 1988. The historical evidence for Jesus, $2^{\text {nd }}$ ed. New York: Prometheus Books.

\section{Internet publications}

Bruce, F F 1959. The New Testament documents: Are they reliable? $5^{\text {th }}$ edition.

Online available:

http://www.ncbible.info/MoodRes/Transmission/NTDocuments-ReliableBruce.pdf. [6 June 2014].

Carrier, R 1999. Thallus: An analysis. In The Secular Web. Online available:

http://infidels.org/library/modern/richard_carrier/thallus.html.

[13 May 2014].

Craig, W L 2014. Thallus on the darkness at noon. In Reasonable faith.

Online available:

http://www.reasonablefaith.org/thallus-on-the-darkness-at-noon [26 June 2014].

Gifford, E H (trans.) 1903. English translation according to Eusebius of Caesarea:

Praeparatio Evangelica (Preparation for the Gospel). Book 10.

In Tertullian.org. Online available:

http://www.tertullian.org/fathers/eusebius_pe_10_book10.htm

[11 August 2014].

Jacoby, F (ed. \& trans.) 1923-1958b. Die Fragmente der griechischen Historiker:

1165; Phlegon history 16a; English translation based on the online edition at the Tertullian Project). Online available:

http://www.tertullian.org/fathers/jerome_chronicle_03_part2.htm

[11 August 2014]. 
Lee, A 2014. Lucian of Samosata: Choking on the camel: Part 2. In Patheos.

Online available:

http://www.patheos.com/blogs/daylightatheism/essays/choking-on-thecamel-part-2/\#lucian [10 July 2014].

Lowder, J J 2000. Josh McDowell's 'Evidence' for Jesus: Is it reliable?

In The Secular Web. Online available:

http://www.infidels.org/library/modern/jeff_lowder/jury/chap5.html

[1 September 2014].

Mackenzie, N \& Knipe, S 2006. Research dilemmas: Paradigms, methods and methodology. In Issues in Educational Research, 16.2:193-205. Online available: http://www.iier.org.au/iier16/mackenzie.html [2 June 2014].

Miller, G 1996. Thallus c. 50-75 AD. In Extrabiblical witnesses to Jesus before 200 AD. Online available: http://christianthinktank.com/jrthal.html.

[6 June 2014].

NASA National Aeronautics and Space Administration Eclipse Website (s.a.) Online available: http://eclipse.gsfc.nasa.gov/eclipse.html [17 July 2014].

The works of Origen (s.a.). Online available:

http://www.john-uebersax.com/plato/origen2.htm [1 June 2014].

Whiston, W (trans.) 1895. Flavius Josephus. The works of Flavius Josephus. Auburn: John E Beardsley. In Perseus Digital Library. Online available: http://www.perseus.tufts.edu/hopper/text?doc=Perseus\%3Atext\%3A1999.0 1.0146\%3Abook\%3D18\%3Awhiston\%20chapter\%3D6\%3Awhiston\%20se ction\%3D4 [ $3^{\text {rd }}$ July 2016]. 